\title{
Paleoliquefaction features on Tenerife (Canary Islands) in Holocene sand deposits
}

\author{
Luis I. González de Vallejo ${ }^{\mathrm{a}, *}$, Meaza Tsigéa Luis Cabrera $^{\mathrm{b}}$ \\ a Departamento de Geodinámica, Facultad de Ciencias Geológicas, Universidad Complutense de Madrid, 28040 Madrid, Spain \\ ${ }^{\mathrm{b}}$ Laboratorio COAC, 38509 Guimar, Tenerife, Spain
}

\begin{abstract}
On Tenerife, one of the Canary Islands, a series of clastic dikes and tubular vents is attributed to liquefaction of sediments during a high-intensity paleoearthquake. Geotechnical, geological, tectonic, and mineralogical investigations have been carried out to identify the soil composition and structure, as well as the geological processes operating in the area. Geochronological analysis has indicated an age ranging from $10,081 \pm 933$ to $3490 \pm 473$ years BP for the liquefaction features. The area in which these liquefaction features are found has undergone tectonic uplift and is affected by two faults. One of these faults was responsible for displacing the Holocene materials. The paleoearthquake responsible for this liquefaction has been analysed in terms of its peak ground acceleration (pga) and magnitude by back calculation analysis based on the cyclic stress and Ishihara methods. A range of $0.22-0.35 \mathrm{~g}$ was obtained for the pga, with the value of $0.30 \mathrm{~g}$ being selected as most representative. From this, an earthquake-modified Mercalli intensity of $I_{\mathrm{MM}}=\mathrm{IX}$ was estimated for the liquefaction site. The magnitude-bound method and energy-based approaches were used to determine the magnitude of the paleoearthquake, providing a moment magnitude $\boldsymbol{M}$ in the range of $6.4-7.2 ; \boldsymbol{M}=6.8$ is taken as the representative figure.
\end{abstract}

Keywords: Tenerife; Canary Islands; Paleoliquefaction; Paleosismicity; Seismites

\section{Introduction}

The Canary Islands (Fig. 1) were formed by the accumulation of volcanic rock that rose above sea level off the western coast of Africa. Positioned immediately east of a deep ocean basin, the islands lie upon a substrate of oceanic-type crust covered by sediments

\footnotetext{
* Corresponding author. Fax: +34 913503876.

E-mail address: vallejo@geo.ucm.es (L.I. González de Vallejo).
}

spanning from the Jurassic to lower Miocene. Seismic profiles on the island of Tenerife indicate that the volcanic block sits on a lithosphere, whose oceanic crust is approximately $6.5 \mathrm{~km}$ in mean thickness, with an elastic layer approximately $20 \mathrm{~km}$ thick. The volcanism that gave rise to the islands began $42 \mathrm{My}$ ago during the Tertiary, primarily as undersea eruptions. Most of the volcanic blocks developed as submarine mountains. This was followed by considerable subaerial volcanism, which is still active today. 


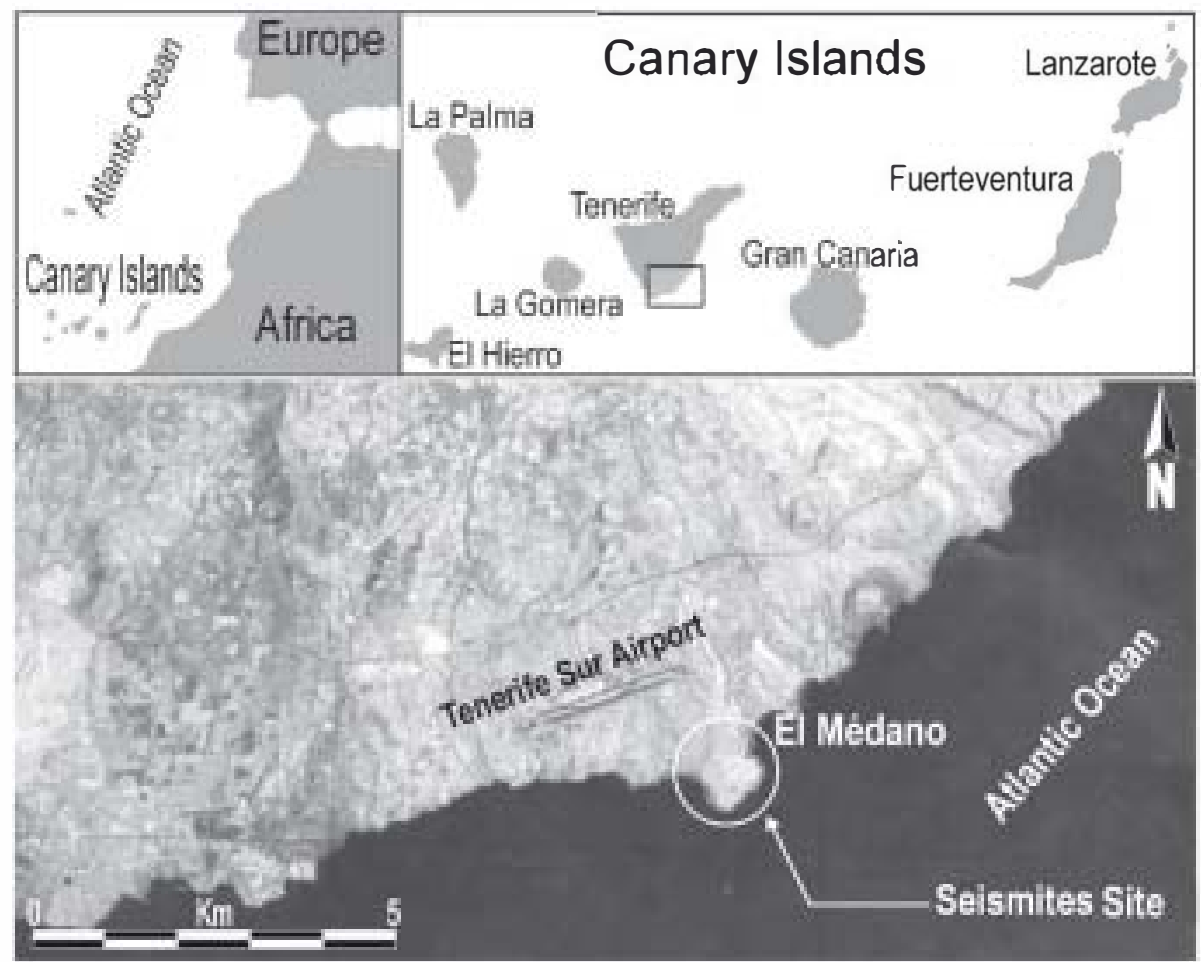

Fig. 1. Regional location of the study area.

The first documented historic eruption $\bullet$ ccurre $\bullet$ the island of Tenerife in 1341, and the most recent was on the island of La Palma in 1971. Tenerife has a record of eight eruptions since the XIV century, the most recent being in 1909.

The Canary Islands have been generally considered as being of low to very low seismicity, with earthquakes always associate with volcanic activity. However, since the establishment of a seismic network in 1975, instrumental records have indicated a very different situation, demonstrating alignments of epicentres and focal mechanisms related to tectonic structures rather than a magmatic origin (Mézcua et al., 1992). Furthermore, geophysical marine investigations have revealed that significant tectonic incidents have been associated with epicentres in the sea. In general, most historic earthquakes have not exceeded a modified Mercalli intensity of $I_{\mathrm{n}}=\mathrm{VI}$, with the exception of those -ccurring during the volcanic eruptions of 1730 on Lanzarote, which according to published descriptions reached an intensity of $\mathrm{X}$. On Tenerife, the maximum intensity recorde was VI. Since installing seismic monitoring instruments, the greatest moment magnitude recorded was $M=5.2$ for the 1989 earthquake, which eccurred between Tenerife and Gran Canaria. There is an obvious need for investigations that focus on paleoseismicity in the Canary Islands, where earthquake information is scarce, the bistoric record is incomplete, and the instrumental period is shorter than $\mathbf{3 0}$ years.

Along the south coast of Tenerife (Fig. 1), several features attributed to liquefaction phenomena were identified in a sandy formation. These findings prompted subsequent tectonic investigations including the ge technical characterization $\bullet$ s sils, mineraløgical and

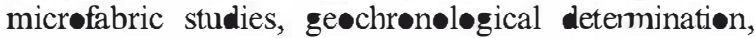
and the analysis of geophysical, seismicity, and netectonic data. We were able to characterize a sand formation as being of Høløcene age, and to identify and describe the liquefaction features within the formation. Possible formation mechanisms and the origin and age of these features were established. In the same area, two faults were identified that had affected the Holocene deposits. Based on the data obtained, estimates were made of the acceleration and magnitude of the 
paleearthquake that gave rise to the features, and possible seismic sources were characterised. The results - this study point to recent tectonic activity being responsible for at least one earthquake, whose strength and magnitude much exceeds those recorded sø far.

\section{Geology of the site}

The site is located in El Médane, close to the Lecadi Machade Beach (Fig. 2). This beach is bounded inshore by a 40- to 50-metre wide range of coastal dunes orientated in a NE-SW direction. Some small lageons have formed between the dunes and a cøastal platform. This platform overlies a formation of volcanic yelløwish tuffs of an acid compesition and descends from the volcanic central part of the island. Towards the SW, a minor volcanic structure, the

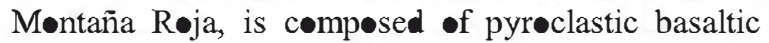
materials that overlie the tuff formation. These materials are covere by a formation comprise of sands and weakly cemented sands, which rises 2 to $15 \mathrm{~m}$ abøve sea level and shows numerous liquefaction features.
The tuffs correspønd to a set of pyrøclastic units related to a stage of explosive salic eruptions between 0.7 and 0.13 Ma. The material is composed of pumice lapilli, lithic fragments, and sanidine crystals. The

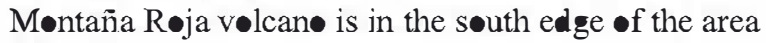
(Fig. 2). It has a shape of a breached cone and open towards the ESE. Its altitude is $150 \mathrm{~m}$ above the lowlands at its base. It is composed of basaltic ash and cinder-type pyroclasts and has been dated as being - lder than 100,000 years.

The beach sand formation comprises bioclastic sands or weakly cemented compact calcarenites and is 2.0 to $2.5 \mathrm{~m}$ thick. Its coarse sand is made up of shell fragments, lithic grains, and plagioclase and pyroxene crystals. The substrate is composed of massive acid tuffs, in which an alteration level $\bullet$ r søfter paleøs $\bullet .5$ $\mathrm{m}$ thick can be $\bullet$ bserved. At søme pøints, it is easy to distinguish a dense network of plant reot structures, indicating that the beach is transgressive and lies upon a densely vegetate surface. In tum, the beach material is covered in some areas by a thin pyroclastic level less than $1 \mathrm{~m}$ thick and by calcareus crusts. The pyrøclastic level contains centimetric size, yelløwish pumice

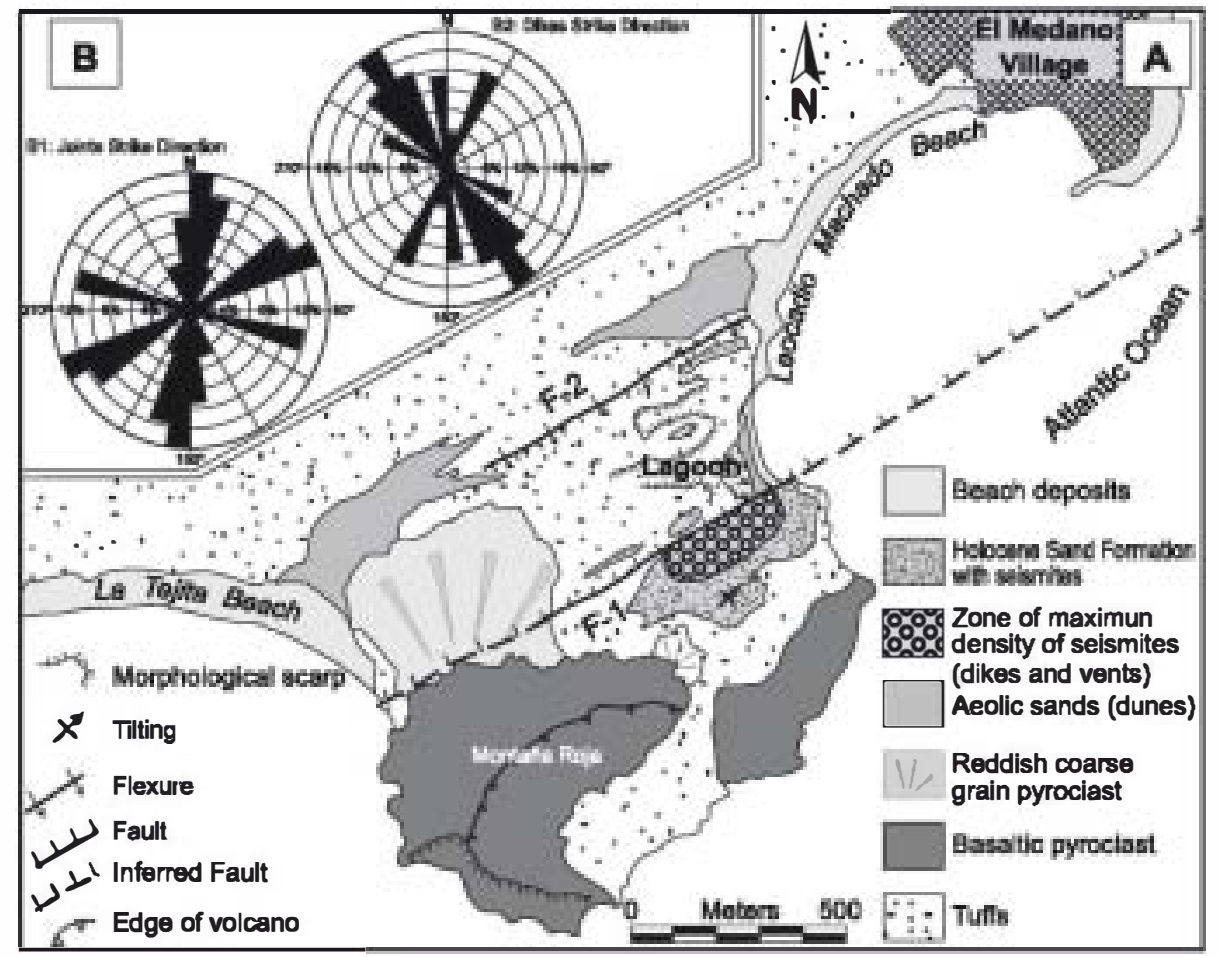

Fig. 2. Geological sketch of the El Médano site (modified from González de Vallejo et al., 2013). 
fragments enveloped by a pumice matrix. The white carbønate crust is laminar in structure and $\mathbf{0 . 1} \mathrm{m}$ thick.

The beach sand formation slightly inclines about $3.5^{\circ}$ towards the NE and is fractured by faults and a network $\bullet$ jøints •rganised in sets (Fig. 2). The most noticeable tectonic structures are two $\mathrm{N} 55^{\circ} \mathrm{E}$ trending faults (F1 and F2) running from the Lecadic Machado beach towards the SW (Fig. 2). The southern fault $\mathrm{F} 1$ is most evident and is marked by an escarpment of 0.7 to $1.2 \mathrm{~m}$, with the SE side facing upwards and dividing the beach and chain of coastal dunes and alsø bounding the inland lageon. The scarp disappears towards the SW, and the fault's trace appears to be covered by recent dunes and a reddishcoloured basaltic pyroclastic deposit, which covers the NW flank of the Montaña Røja velcan॰. Thus, the trace of the fault F1 can be followed $1.2 \mathrm{~km}$ inland, although it extends under the sea at both of its extreme ends. Several seismic reflection profiles on the

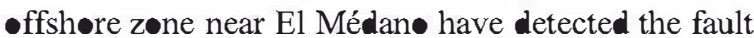
$\mathrm{F} 1$, with a minimum length of $5 \mathrm{~km}$ (Gønzález de Vallej• et a1., 2003). The northern fault F2 (Fig. 2) is marked by a less-pronounced morphølegical scarp. This fault is best observed at the NE end of the mapped area and fades out until it disappears at the SW end. The fault is marked by a slight flexure that produces a scarp $0.5 \mathrm{~m}$ high with more erosion of the footwall. A vertical displacement of 0.7 to $1.2 \mathrm{~m}$ has been observed in fault F1. The time of displacements postdates to at least the time of formation of the beach, dated as Holocene as described below.

A set of highly continuous fractures interpreted as jøints mainly affects the tuff formation (Fig. 2). Søme of these joints, nevertheless, show an intensely curved trace. Although relatively small in number for the area, their inclination was determined as being always vertical or close to $\mathbf{9 0}^{\circ}$. The most common alignments define three sets $\bullet$ j joints, whose directions in order of highest to lowest frequency are $\mathrm{N} 175^{\circ}, \mathrm{N} 56^{\circ}$, and $\mathrm{N} 105^{\circ}$.

\section{Liquefaction features}

The liquefaction features are found in the uplifted beach sand formation. This formation extends over an area of around $90,000 \mathrm{~m}^{2}$ but could have reached $650,000 \mathrm{~m}^{2}$ in the last 50 years. Changes produced in cœastal dynamics and anthrøponenic effects have substantially modified the zone during recent decades, with almost complete disappearance of the dunes and acceleration of erøsive processes. Artificial removal of a large proportion of the uplifted beach sands has led to the current appearance of the study area.

The section observed in the site was as follows, from top to bottom:

- An upper layer H1 located at the top of the deposit compose of coarse to intermediate highly compact, partially cemented sands. Its thickness is approximately $1 \mathrm{~m}$. The surface is intensely eroded and shows wind erosion structures indicating its thickness was larger and may have reached at least $2 \mathrm{~m}$. This layer shows evidence of liquefaction structures in the forms of sand-filled tabular sand dikes and open circular vents (described below in detail). Above this layer appear small calcareous crusts of centimetric thickness and altered tuffs.

- The lower layer $\mathrm{H} 2$, beneath the previous layer, is comprised of medium t॰ coarse sands, sømewhat finer and less compact than in layer H1. It shøws lamination and cross-stratification. This layer is partially crossed by vents but not dikes. Its thickness ranges from 0.5 to $1 \mathrm{~m}$.

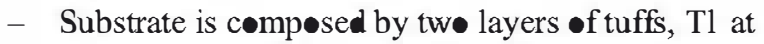
the top and T2 at the bottom. T1 is composed of reddish tuffs weathere to form a $0.5-\mathrm{m}$ thick pale $\bullet 1$. T2 is forme of massive, highly compact pumice tuffs.

Within the layers $\mathrm{H} 1$ and $\mathrm{H} 2$ are numerous open vents and clastic dikes that we interpret as having a seismic liquefaction origin (Fig. 3). These outcrop both on the horizontal surface (plan view) and in natural exposures in sectional view. The dikes (Fig. 4) are filled with sands of the same composition of layer $\mathrm{H} 2$, with strikes $\bullet 145^{\circ}, 25^{\circ}, 5^{\circ}$, and $110^{\circ}$. The dikes with strikes of $145^{\circ}$, besides being the most frequent, lie almost perpendicular to the direction of the topøgraphical slope, while those with a trend of $110^{\circ}$ show similar directions to the $105^{\circ}$ striking joints. In the mapped area, the length of the dikes is as much as $25-30 \mathrm{~m}$, althøugh they are not easy to observe because of the intense erosion and dune deposits that partly cover them. The most common thickness (in plan view) is 4 to $8 \mathrm{~cm}$, although in some cases, thicknesses of up to $20 \mathrm{~cm}$ have been measured. Many of these dikes have a central 


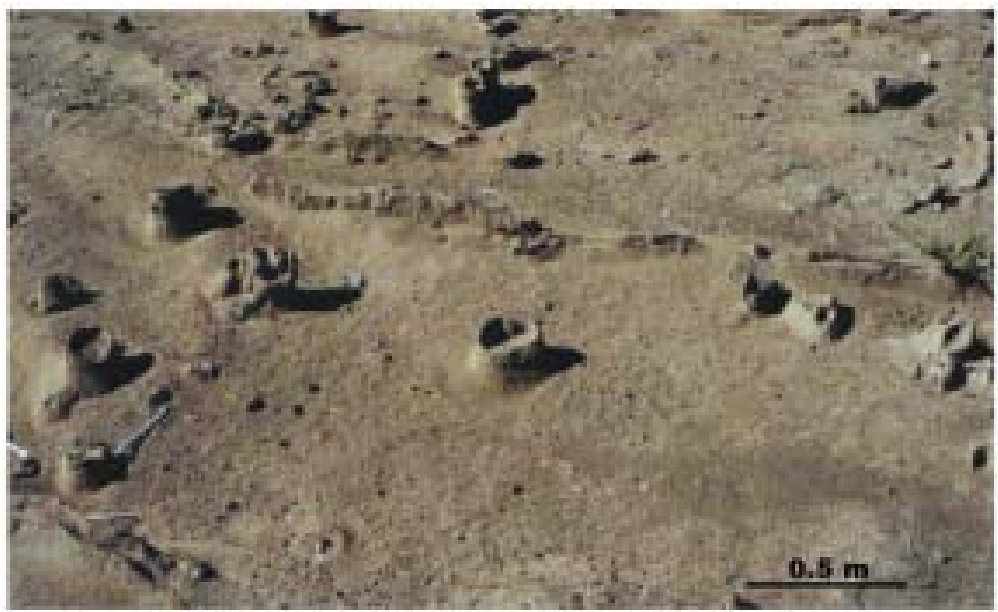

Fig. 3. Liquefaction features showing some tubular vents and tabular clastic dikes. The tubular vents are manifested as the raised circular features, and the tabular dikes as the raised, more or less linear features.

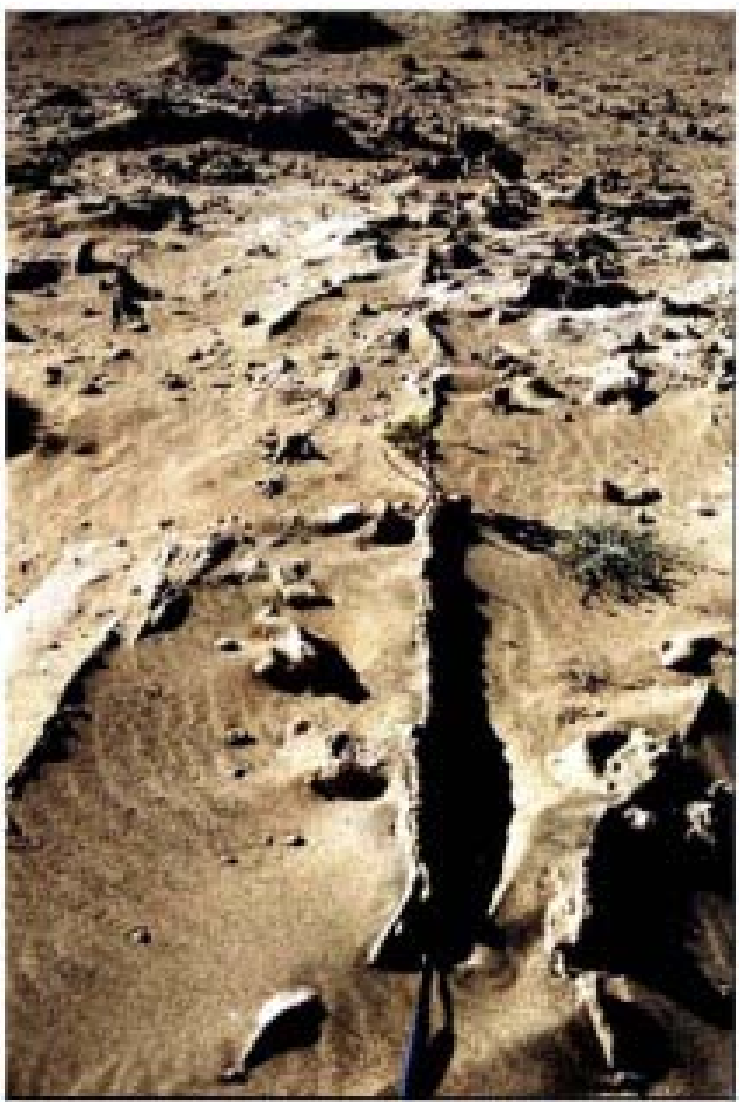

Fig. 4. Tabular stuctures forming typical clastic dikes at the site. opening or double rim ranging from 0.5 to $1.0 \mathrm{~cm}$ wide. The main system $\left(145^{\circ}\right)$ is the most continuous and shows the greatest thickness. The dikes show lateral terminations in the shape of thin filaments up to $1 \mathrm{~cm}$ long. At some places, they cut into each other and alsø cut the tubular structures. The tabular features contain material with grain sizes different from the host that the features penetrate (Fig. 5). In some cases, the sediment in the tabular fillings has sediment coarser that the host, and at many places on the lower portion of the slope, the sediment in the tabular fillings is finer.

The formative mechanisms of the clastic dikes seem to be related to lateral spreading and hydraulic fracturing (Obermeier, 1996). The orientation of the main system $\left(145^{\circ}\right)$ is perpendicular to the slope, and its greater thickness and continuity in relation to the other systems could be explained by a mechanism of lateral spreading. Lateral spreading reflects translational movement downslope and separation between individual blocks (Obermeier et al., 1993). Movement -ccurs where there is $\bullet$ nly minør resistance to lateral translation of the cap sitting on liquefied sediment. Besides lateral spreading, the geometry of the dikes $\left(145^{\circ}\right.$ and the other directions), their orientation, injected material, apical terminations, and central apertures all pøint to a hydraulic fracturing mechanism.

The sand formation alse shows numerous tubular features in the shape of vents with diameters of 8 to 20 $\mathrm{cm}$ (Fig. 6), whose greatest density coincides with a zone close to and parallel to the scarp for fault F1. 


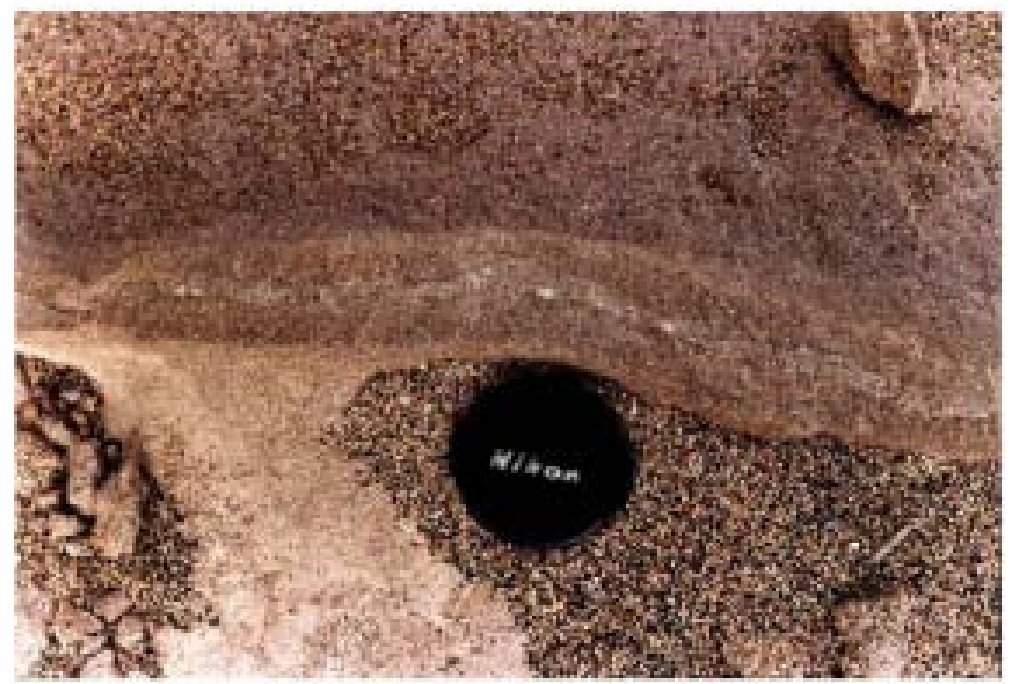

Fig. 5. Detail of clastic dike showing flling of sediments.

These features are much more randomly scattered throughout the site than the tabular features. They are all nearly circular in plan view (Fig. 3). They are found at places which either cut or are cut by the tabular features, with the correct altemative being indeterminate. Where they could be observed (partially) in vertical section, for a metre or more beneath the modern surface, their diameters appear to be uniform regarding to depth. These tubes have a very compact peripheral ring with secondary infilling materials of loose sand inside them. Owing to the greater compactness of the ring, eresion has preserved the structures, and these may be seen in the outcrops. These structures are present from the lower layer $\mathrm{H} 2$ upwards and cross the upper layer H1. In the zone of highest density, they -ccur at 3 to 5 per $\mathrm{m}^{2}$, the average being 2 per $\mathrm{m}^{2}$.

\section{Mineralogical composition and microfabric}

T• investigate the mineraløgical compøsition and micrefabric structure of the beach sand formation, as

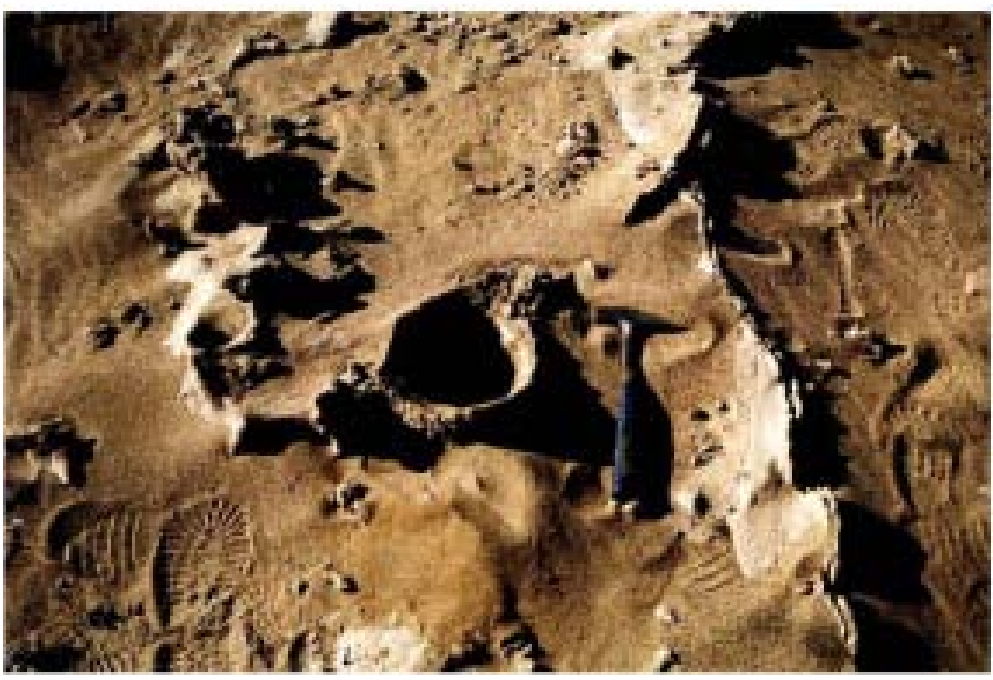

Fig. 6. Tubular structures forming vents. 
well as the tubular features, several samples were analysed in thin sections by optical microscope and scarming electronic microscope (SEM). Mineraløgical compesition of the sands and the tubular features are mainly composed of calcite crystals of biogenic origin and fragments of pyroclasts composed of feldspars and $\bullet$ livine. Very small colløidal quartzs, with sizes less than $1 \mu \mathrm{m}$, are alsø present, showing laminar shapes with irregular edges.

The sand-sized particles are cemented by a very thin material composed of a micritic mixture of calcite and/or dolømite and a mudlike material of aluminum silicates (Al, Si, Ca, Na; Fig. 7). However, the micritic mixture in the sand formation is composed of calcite, whereas in the tubular features, this mixture is compose of dolomite $(<0.25 \mu \mathrm{m})$. Small crystals of calcium sulphates were $\bullet$ bserved in the tubular features. Neither organic remains nor bioturbation structures were observed in the tubular features.

Optical microscopes were used to identify the textures of the sands, and SEM was used to $\bullet$ bserve the microfabric of the tubular vents. Columnar-type textures were observed in the sand formation, as well as in the tubular vents (Fig. 7). The clastic particles are bonded by bridges of micritic cement. The studied samples are relatively dense. The microfabric of the sand formation, inferred from the SEM, has a metastable structure of a høneycømb-like •pen arrangement composed of small crystals of biøorganic calcite (Fig. 8) accompanied by significant feldspars and elivine. These crystals are connected by a mudlike, large, fine-grained bridge (Fig. 9). This mudlike material cements the fine sand and silt-sized calcite crystals and is composed predominantly of aluminium silicate materials and a small amount of calcite and dolømite crystals. The micrestructure

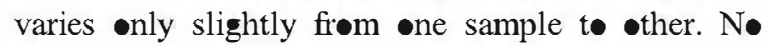
intergranular cementation between the large sand crystals was •bserved. The porøsity of the sand formation is relatively high, approximately $50 \%$, mainly due to macropores $(>5 \mu \mathrm{m})$ between the sand and silt-size grains. The sand particles have $7 \mu \mathrm{m}$ of mean diameter and are generally larger than the voids. Microveids are als observed in the cementing material, but in this case, the voids are not connected. The microfabric of the tubular features has a much higher density than the sand formation hosting the features.

The presence of dølømitic and aluminium silicates is characteristic of postsedimentary processes. Magnesium carbonates are typical of the marine environments where the sand formation was formed, $15 \mathrm{~m}$ above sea level at present. Alumi-

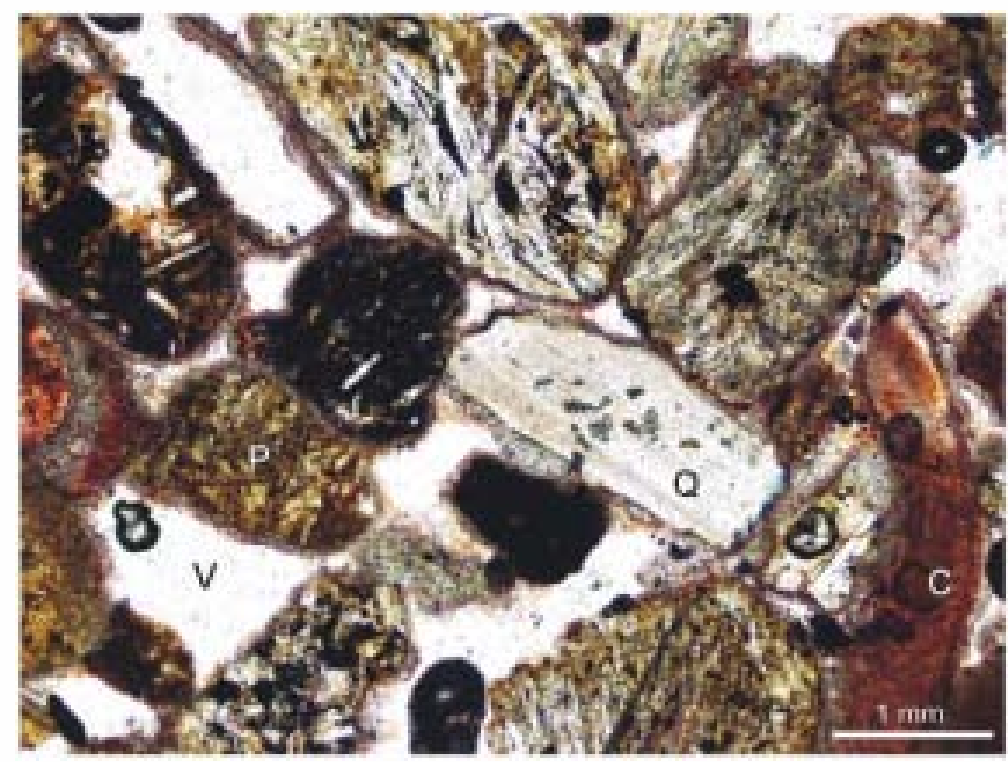

Fig. 7. Optical micrograph showing typical feature of the sand formation, where the bioorganic calcite crystals and feldspars are cemented by a mixture of $\mathrm{Al}, \mathrm{Si}, \mathrm{Na}, \mathrm{Ca}$ mud and micritic calcite forming a cohummar-like texture. V: voids; Q: quartz; C: calcite; P: pyroclast. 


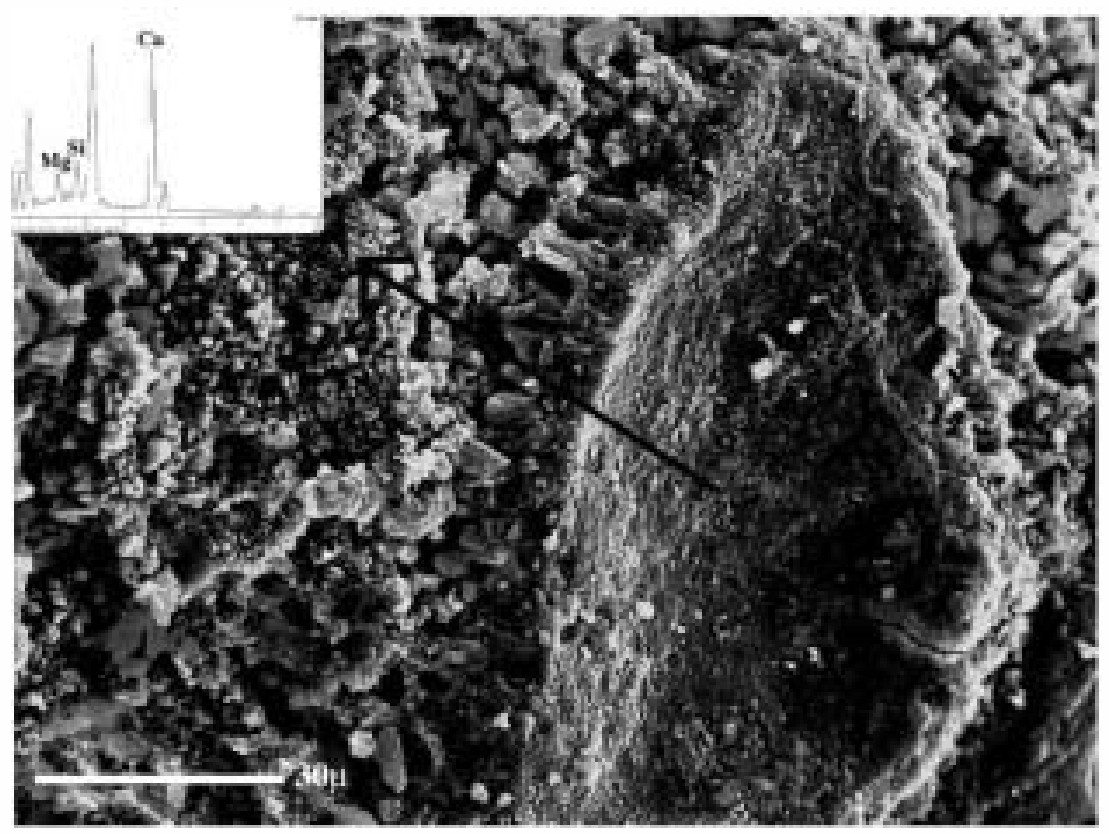

Fig. 8. Crystal-connector-crystal type microsmucture of the tubular features seen with SEM. The sand-sized calcites are connected by a bridge of mud aggregate formed by small dolomite crystals and $\mathrm{Al}, \mathrm{Si}, \mathrm{Mg}, \mathrm{Na}, \mathrm{Ca}$.

nium silicates are commøn in volcanic ashes. These silicates can react with carbonates, with a quick prøcess of hardening. These gechemical prøcesses could explain the hardening and cementation that affects the sand formation and the liquefaction features.

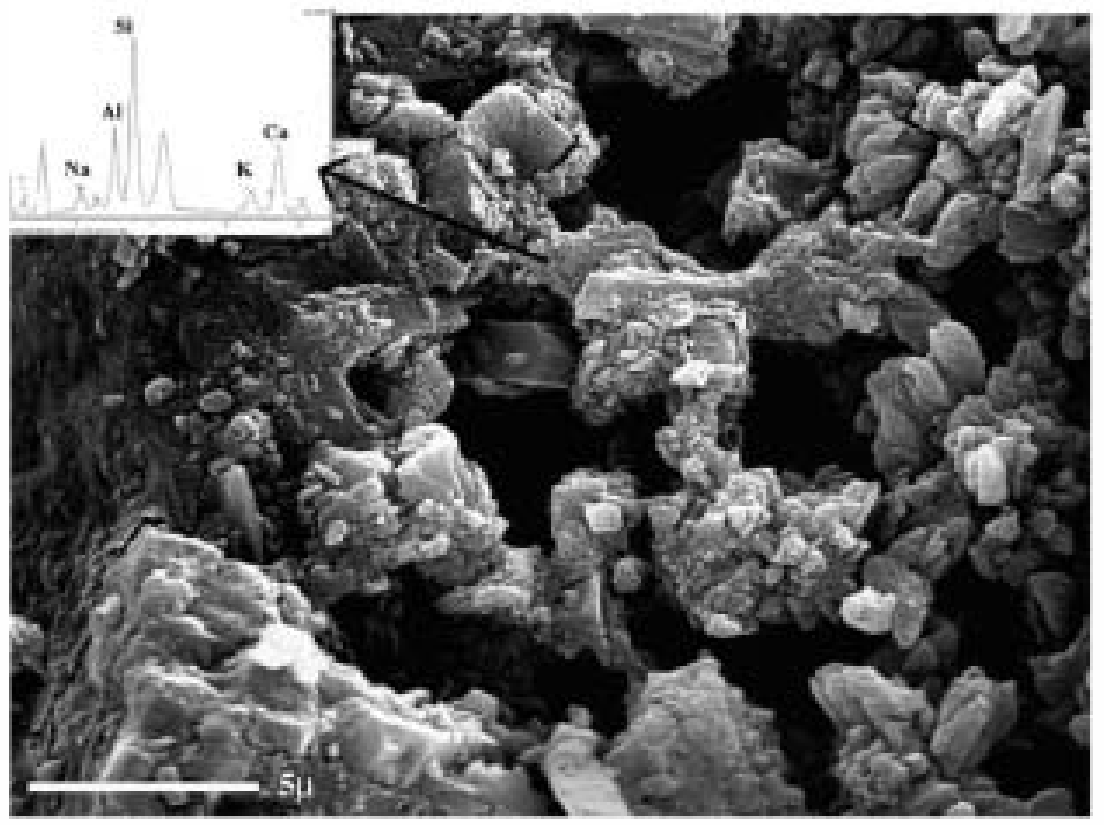

Fig. 9. A detailed view of the aggregate cement. 


\section{Origin of the liquefaction features}

T• establish the origin $\bullet$ the liquefaction features, possible causes of both seismic and aseismic natures were analysed. Volcanic activity can generate structures that give rise to vents or tubular conduits, injection of materials, fractures, infills, alterations, etc., as a consequence of the ejection of fluids, gases, and other materials. The last volcanic episøde registered in the area took place over 100,000 years age, while the age of the beach deposits is of the order of 10,000 years, as described below. The dikes and vents only affect the paleobeach sand formation and not the tuffs of the substrate. These reasøns rule out a direct relation with any volcanic activity. Minerals assøciated with hydrothermal processes were nøt found.

Some marine and coastal organisms can produce channels and orifices in beach deposits. A preexisting hole that served as a conduit for venting might have formed from decayed roots or by some type of animal digging. However, n॰ evidence of organic material remains of bioturbation processes was found in ๑utcrøps or by microscope. Althøugh this is still an -pen question that may be resølved by further research at the site and other areas in the region, the present data do n॰t support a biøløgical $\bullet$ rigin.

Pounding sea waves and tsunamis produced by large offshore displacements of the sea bed are highly improbable in this zone. The most recent landslide, in the valley of Guimar ( $35 \mathrm{~km}$ east of El Médan•), -ccurred arøund 0.8 Ma (Massøn and Watts, 1995). Althøugh tsunamis or submarine sløpe failures of seismic origin cannot be ruled out, deposits assøciated with these have not been found in the study area. Nevertheless, this hypothesis is unlikely, given the distribution and orientation of the liquefaction structures.

The evidence supporting a seismic origin is based on the mechanism of upward hydraulic forces being exerted rapidly or almost instantly. Hydraulic fracturing at high pressures is indicated by (1) the presence - f tabular dike-filled sands transported upward, (2) by the apertures or double rims in the dikes containing material with grain sizes different from the host, and (3) by the dikes having apical terminations. Thus, this gelogical evidence shows that virtually all the dikes could almost certainly have formed sølely in respønse to hydraulic fracturing (Obermeier, 1996). A seismic liquefaction origin is indicated by the fact that the direction of the tabular dikes is not random as would be expected if the dikes had been originated by nonseismic mechanisms. The granulometric characteristics of the sand layers and their high uniformity and high porøsity with connected voids may be indicative of high susceptibility to liquefaction of the deposits.

On the basis of the abøve evidence, we rule out a nonseismic origin and support a seismic origin for the tabular dikes. This idea is alse consistent with the seismotectonic characteristics of the region and the proximity of the previously described faults.

The principal mechanism giving rise to the tabular structures is interpreted to be liquefaction of the lower layer $(\mathrm{H} 2)$ of saturated sands. Due to the effect of intense interstitial pressures, water and sand were transported and expelled towards the surface, possibly als forming the circular vents. Hydraulic fracturing or lateral spreading led to rupture of the upper layer (H1) of compact sands, giving rise to sand dike injection.

The possibility of more than one earthquake -ccurring in the zone should not be precluded because -f the presence of dikes cutting the vents. That could imply more than one phase of liquefaction.

The beach sand formation has been dated as Høløcene by thermoluminescence (Millán et a1., 2002 as $10,081 \pm 933$ years BP). The calcareous crusts that cover some of the liquefaction structures have been date by the same technique as $3490 \pm 473$ years BP. According to these data, liquefaction and the seismic phenomenon that produced it took place prior to 3490 years age but after 10,000 years age.

\section{Estimates of acceleration and magnitude of the} paleoearthquake

The force $\bullet$ a seismic event and the magnitude of a paleearthquake can be estimated by several methøds, reviewe in detail by Obermeier et al. (2001). The following methods are applicable to the present case:

(a) The cyclic stress meth $\bullet$ based on estimates of the lower-bound peak ground acceleration at individual sites of liquefaction. 
(b) The Ishihara methød, which uses dike height at the site of hydraulic fracturing to estimate the actual value of peak ground acceleration at the site.

(c) The magnitude bound method, which uses the furthest distance from the seismic source to the liquefaction zone.

(d) Energy-based solutions.

Methods (a) and (b) serve to calculate the peak acceleration needed for liquefaction to initiate at a particular site. The cyclic stress method is based on the method of Seed and Idriss (1971) and subsequent updates by Seed et al. (1985) and Youd and Noble (1997). Its application requires the interpretation of the søil prøfile at the time $\bullet$ liquefaction. T• this end, we took int account the current conditions of the sand depesit and the processes to which the søil has been subjected from the time of liquefaction to the present.

The most common processes affecting pale liquefaction interpretations are the following (Olsøn et al., 2001): destruction of preearthquake søil structure and aging effects during liquefaction; postliquefaction conselidation and densification; and postliquefaction aging. The main outcome of liquefaction is an increase in granular packing, which may compact the sediment very significantly (Owen, 1987). Føllowing depesition, natural and mamnade deposits develøp a structure resulting from postdepositional mechanical readjustment and possible weak chemical bønding at particle contacts. This process is referred to as aging. The development of søil structure results in the improvement of soil properties, such as shear strength, modulus, and penetration resistance (Schmertmarm, 1991).

The present uplifted sand beach depesits at El Médan• shøw evidence for these aging prøcesses. The main factors that have contributed to the compaction and partial cementation of the upper layer $(\mathrm{H} 1)$ are as follows: uplift of the deposits by tectonics and the downdropping of the water table, gechemical conditions of the envirøment that favoured an input of calcium carbonates and aluminium silicates compounds, and the extremely arid climatic conditions. Sands that could show conditions previous to aging processes were identified. These sands $\bullet c c u r$ in the vicinity of the site closest to the coast and show the typical site granulømetry and compesition. Priør to liquefaction, the søil profile may have been as follows:

- An upper layer (H1) made up of cœarse t॰ medium sands, dense to very dense with less than $2 \%$ fines, apparent natural density $1.7 \mathrm{~g} / \mathrm{cm}^{3}$, and $N_{\text {SPT }}$ equal to or more than 30 blows. Estimated mean thickness was $2 \mathrm{~m}$. The water table would have lain towards the base of this layer, which would have been subjected to variations in the water table. Behaviour of layer $\mathrm{H} 1$ could correspond to that of a hard, semiconfining, and nonliquefiable layer.

- A lower layer $(\mathrm{H} 2)$ comprised of medium to coarse sands, relative density intermediate, containing less than $2 \%$ highly uniform fines, apparent natural density $1.5 \mathrm{~g} / \mathrm{cm}^{3}$, and $V_{\text {SPT }}$ between 15 and 20 blows. The water table would lie above this layer and would therefore be saturated. Mean estimate thickness is $1 \mathrm{~m}$. This layer would act as a source zone for liquefaction.

- Layer T1, substrate beneath H2, containing red tuffs weathered to $0.5-\mathrm{m}$ thick paleosøls.

- Layer T2, substrate beneath H2, composed of massive very compact tuffs.

The cyclic stress method was applied following these hypotheses to estimate the peak ground acceleration (pga) necessary for the soil to underge liquefaction for a value $\bullet \boldsymbol{M}=7.5$. The results $\bullet$ btained give an acceleration $0.22 \mathrm{~g}$ for $\left(N_{1}\right)_{6 \bullet}=15$ and $0.30 \mathrm{~g}$ for $\left(V_{1}\right)_{6}=20$. According to Youd and Noble (1997), this would correspond to a $50 \%$ probability of liquefaction.

The Ishihara (1985) method considers that the maximum height of dikes is controlled by tw॰ factors: the thickness of liquefied sediment and the pga. This method appears to be valid for seismic structures produced by hydraulic fracturing. It is applicable where the cap thickness is reasonably uniform and when søurce sands range from very løose to moderately compact, at least for earthquakes of moment magnitude $\boldsymbol{M} \sim 7.5$ or larger (Obermeier, 1998). For back-analysis at the site, it was considered that the hard, semiconfining, nonliquefiable layer was $2 \mathrm{~m}$ in thickness, and a thickness of $1 \mathrm{~m}$ was assumed for the 
liquefiable source. For these conditions, the resulting pga was $0.35 \mathrm{~g}$ according to the Ishihara method. Bearing in mind that the cyclic stress method represents the minimum acceleration value and the Ishihara method considers average conditions, a representative value of $0.30 \mathrm{~g}$ was selected from the possible range between 0.22 and $0.35 \mathrm{~g}$.

By using the calculated accelerations, intensities at the site can be estimated using one of the available empirical expressions. The equation used in the Spanish Seismic Code is $I=\left[3.2233+\log _{1} \bullet(a / g)\right] /$ 0.30103 , where $I$ are intensities, $a$ is the horizontal pga $\left(\mathrm{cm} / \mathrm{s}^{2}\right)$, and $g$ is in percent gravity. Hence, an acceleration of $0.30 \mathrm{~g}$ gives an intensity of $I_{\mathrm{MM}}=\mathrm{LX}$.

The magnitude of a pale earthquake, in terms of the moment magnitude $\boldsymbol{M}$, can be calculated by using the magnitude-bound methød and energy-based approaches. The magnitude-bøund methød estimates the magnitude of a paleoearthquake using relations between earthquake magnitude and the distance from the tectonic source to the farthest site of liquefaction. The method is based on worldwide historical earthquakes (Ambraseys, 1988) and the data described by Obermeier et al. (1993) and Pond (1996). This method requires the identification of the seismic source. In the present case, the closest seismic sources are found between Tenerife and Gran Canaria, over a line of epicentres in the ocean located approximately $35 \mathrm{~km}$ frøm the El Médan॰ site. This søurce is assøciated with a NE-SW trending $\bullet$ ceanic fault that runs parallel to the eastern coast of Tenerife and was inferred from gravimetric data by Besshard and MacFarlane (1970). In 1989, it produce the greatest earthquake instrumentally recorded on the archipelage $(\boldsymbol{M}=5.2)$. The length attributed to this fault was $30 \mathrm{~km}$ (Mézcua et al., 1992); however, in fact, it extends to over $80 \mathrm{~km}$. A further possible seismic søurce is fault F1 løcated at the site. Its proløngation beneath the $\bullet$ cean was established by reflection seismic profiles indicating a minimum length of $5 \mathrm{~km}$ (Gønzález de Vallej• et a1., 2003). However, the instrumental record shows n॰ reference to earthquakes with epicentres close to this fault, and hence we only considered the ecean fault $35 \mathrm{~km}$ from the site as a seismic source when calculating the earthquake magnitude; this yielded a value $\bullet \boldsymbol{M}$ in the range 6.4 to 6.8 . Given that 6.4 is the lower limit of the data considere by Ambraseys (1988), we took $\boldsymbol{M}=6.8$ as being representative. Wells and Coppersmith's
(1994) relationship between fault length and magnitude alsø gives a value of $\boldsymbol{M}=6.8$.

The second method used to estimate magnitude is based on the s-called energy-based approaches that relate magnitude to energy release (Davis and Berril, 1982 and subsequent reviews by Berril and Davis, 1985; Trifimac, 1995). This method relates magnitude to distance from the epicentre to the liquefaction site and the $\left(N_{1}\right)_{6 \bullet}$. For $\left(V_{1}\right)_{6 \bullet}=20$, the results $\bullet$ btained indicate a magnitude $\boldsymbol{M}=6.8$ according to Berril and Davis (1985), and 7.2 according to Trifunac (1995).

In summary, the magnitudes estimated are in the range 6.4 to 7.2 , with a value of $M=6.8$ being considered the most representative. These estimates were based on the assumption that the seismic source was the submarine fault. However, considering fault Fl closer to the site as the source of seismicity yields lower magnitudes but similar accelerations.

\section{Conclusions}

In the El Médan॰, søuth of Tenerife, several liquefaction structures were identified consisting of clastic-filled tabular dikes and large open tubular vents, whose origin is attributed to the liquefaction of sands by an earthquake of large intensity.

Mineraløgical compøsition and micrøabric studies have shown the presence of a metastable structure of high porøsity with connected voids prone to liquefaction phenomena. Micritic carbonates and aluminium silicates mud are the main cement materials formed by postsedimentary processes.

The mechanisms that gave rise to the clastic dikes were hydraulic fracturing and lateral spreading of a level of compact sands in response to high pore pressures of seismic origin. These pressures, in tum, led to the movement and injection of sands across the compact sands level. The open vents are possibly the result of high upward hydraulic pressures causing the ejection of water and sand through these conduits to the

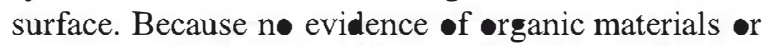
biøturbation prøcesses was found, nor minerals ass $\bullet$ ciated with hydrothermalism, the origin of the tubular features is still an open question to be resolved by further research.

The liquefaction features developed over a tectonically uplifted beach of sand deposits were dated as 
$10,081 \pm 933$ years BP. Lying abøve these sands and liquefaction structures are fine calcareous crust levels date as $3490 \pm 473$ years BP. The paleearthquake responsible for liquefaction occurred during the Holøcene, and its age lies within this range. Nevertheless, tectønic data and geomørphøløical field -bservations indicate an age closer to the more recent.

The peak ground acceleration required to produce liquefaction and the sand dikes was estimated at 0.22 to $0.35 \mathrm{~g}$. An acceleration $0.30 \mathrm{~g}$, considered to be the most characteristic, would correspond to an intensity $\bullet$ IX at the site of liquefaction. The magnitude of the earthquake causing liquefaction was calculated to be in the range 6.4 to 7.2 ; a value of $\boldsymbol{M}=6.8$ is taken to be representative. This result was $\bullet$ btained considering the submarine fault as the seismic source. According to the seismic record, this pale earthquake is the largest of those registered on the Canary Islands.

\section{Acknowledgements}

Helpful comments and advice were received by Dr. S. F. Obermeier of the U.S. Geøløical Survey

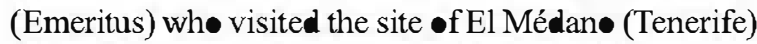
and discussed with the authors the origin of the liquefaction features. We als $\bullet$ thank the cøllabøration of J.M. Insua from Universidad Complutense de Madrid for his help during the preparation of this paper.

\section{References}

Ambraseys, N., 1988. Engineering seismology. Earthquake Engineering and Smuctural Dynamics 17 (1), 1-105.

Berril, J.B., Davis, R.@., 1985. Energy dissipation and seismic liquefaction of sands revised model. Soils and foundations (Japanese Society of Soil Mechanics and Foundation Engineering) 25 (2), $106-108$.

Bosshard, E., MacFarlane, D.J., 1970. Crustal smucture of the westem Canary Islands from seismic refraction and gravity data Journal of Geophysical Research 75, 4901-4918.

Davis, R.•., Berril, J.B., 1982. Energy dissipation and seismic liquefaction of sands. Earthquake Engineering and Smuctural Dynamics 10, 59-68.

González de Vallejo, L.I., Capote, R., Cabrera, L., Insua, J.M., 2003. Paleosismicidad y sismotectónica en el Sur de Tenerife. In: $\mathbf{2}^{\bullet}$ Congreso Nacional de Ingeniería Sísmica, vol. 1. Asociación Española de Ingeniería Sísmica, Malaga, Spain, pp. 75-84.

Ishihara, K., 1985. Stability of natural soils during earthquakes. In: Proc. 11th International Conference on Soil Mechanics and
Foundation Engineering, vol. 1, San Francisco, CA. A.A. Balkema, Rotterdam, pp. 321-376.

Masson, D.G., Watts, A.B., 1995. Slope failures and debris avalanches on the flanks of volcanic islands: the Canary Islands, off northwest Africa. Landslide News 9, 21-24.

Mézcua, J., Buforn, E., Udías, A., Rueda, J., 1992. Seismotectonic of the Canary Islands. Tectonophysics 208, 447-452.

Millán, A., Benitez, P., Calderón, T., 2002. Datación Absoluta por Termohuniniscencia de Muestras de Paleoplayas de Tenerife. Laboratorio de Datación y Radioquímica, Universidad Autónoma de Madrid. Unpublished.

Obermeier, S.F., 1996. Use of liquefaction-induced features for paleoseismic analysis. Engineering Geology 44, 1-76.

Obermeier, S.F., 1998. Overview of liquefaction evidence for strong earthquakes of Holocene and latest Pleistocene ages in the states of Indiana and Illinois, USA. Engineering Geology 50, 227-254.

Obermeier, S.F., Martin, J.R., Frankel, T.L., Munson, P.J., Munson, C.A., Pond, E.C., 1993. Liquefaction evidence for one or more strong Holocene earthquakes in the Wabash Valley of southem Indiana and Illinois. United States Geological Survey Professional Paper 1536. 27 pp.

Obenneier, S.F., Pond, E.C., Olson, S.C., 2001. Paleoseismic studies in continental settings: geological and geotechnical features in interpretations and back-analysis. U.S. Geological Survey Open-File Report 1-2g, 53pp.

Olson, S.M., Obermeier, S.F., Stark, T.D., 2001. Interpretation of penetration resistance for back-analysis at sites of previous liquefaction. Seismological Research Letters 72 (1), 46-59.

Owen, H.G., 1987. Deformation processes in unconsolidated sands. In: Jones, E.M., Preston, M.F. (Eds.), Deformation of Sediments and Sedimentary Rocks, Geological Society of London Publ., vol. 29. pp. 11-24.

Pond, E.C., 1996. Seismic parameters for the central United States based on paleoliquefaction evidence in the Wabash Valley. $\mathrm{Ph}$ thesis. Virginia Polytechnical Institute Blacksburg, VA, $583 \mathrm{pp}$.

Schmermann, J.H., 1991. The mechanical aging of soils. ASCE J. Geotech. Eng. Div. 117 (1), 1288-1330.

Seed, H.B., Idriss, I.M., 1971. Simplified procedure for evaluating soil liquefaction potential. ASCE J. Soil Mech. Found. Eng. Div. 97 (1), $1249-1273$.

Seed, H.B., Tokimatsu, K., Harder, L.F., Chung, R.M., 1985 Influence of SPT procedures in soil liquefaction resistance evaluations. ASCE J. Soil Mech. Found. Eng. Div. 111, $1425-1445$.

Trifunac, M.D., 1995. Empirical criteria for liquefaction in sands via standard peneration test and seismic wave energy. Soil Dynamics and Earthquake Engineering 14, 419-426.

Wells, D.L., Coppersmith, K.J., 1994. New empirical relationships among magnitude, rupture length, rupture area, and surface displacement. Bulletin of the Seismological Society of America 84, 974-1002.

Youd, T.L., Noble, K., 1997. Liquefaction criteria based on statistical and probabilistic analysis. Youd, T. L. and Idriss, I. M. (Eds.) Proceedings of the NCEER Workshop on Evaluation of Liquefaction Resistance of Soils. Tech. Rep. NCEER 97-0022, State University of New York at Buffalo, NY, pp. 210-216. 